Scratches in the earth -the underworld as a theme in British prehistory, with particular reference to the Neolithic and earlier Bronze Age

PAUL DAVIES ${ }^{1}$ AND JOHN G. ROBB

${ }^{1}$ Corresponding author. Graduate School and Dept. of Geography, Bath Spa University College, Newton Park, Newton St Loe, Bath BA2 9BN. 


\title{
Scratches in the earth -the underworld as a theme in British prehistory, with particular reference to the Neolithic and earlier Bronze Age
}

\begin{abstract}
This paper catalogues and considers a number of examples where authors have invoked the concept of an underworld in explaining various prehistoric activities. In drawing this material together it is hoped that the case for exploring the underworld as a general theme in pre-Iron Age Britain is made. In addition, the paper considers the usefulness of looking at various prehistoric activities from the perspective of the underworld. In particular the phenomenon of inversion is considered.

Keywords: Prehistory, underworld, inversion, archaeology
\end{abstract}

INTRODUCTION

"The sun and the stars dip below the horizon, which suggests the existence of an underworld" (Yi Fu Tuan 1974, p.131)

"The people of Neolithic times did not think solely in terms of what was in the sky or above their heads. The Earth had life too." (Francis Pryor 2001, p.180)

This paper has two primary intentions. First, to point out that while British archaeologists have generally been reluctant to discuss the underworld as a theme in the Neolithic and earlier Bronze ages, they have been more forthcoming in invoking the notion of an underworld with respect to limited phenomena at limited locations at limited times. When one collates even a fraction of this material it would seem that there is a wider theme to be considered for these periods as well as for the Iron Age where the underworld as a theme has been more readily invoked (e.g. Miranda Green 1986). The second intention of this paper is to consider how 'perspectives' of, or from, the underworld may contribute to the discussion of the 'meaning' of a variety of ritual acts and ritual sites.

In achieving these intentions a few caveats are required. First, although there are often references to monument 'types' and the 'natural' and 'artificial', it is accepted - and indeed hopefully seen later as vital - that one should not lose sight of the general point that at some times in the past the distinction between artificial and natural features may have been less clear, with some natural features perhaps being considered as 'constructions' by past populations or ancestors and vice versa (see, for example Tilley and Bennett 2001). Where separations have occurred here they are often for heuristic purposes only.

Second, we have not attempted to be comprehensive in discovering every reference to the underworld in the recent archaeological literature - as it is the paper is already considerably longer than first envisaged. We have also been deliberately selective, relying quite intentionally on recent syntheses where one expects themes to be highlighted. This selectivity has also allowed us to try and see beyond the differences between 'sites' or 'natural features' of the same type, and to concentrate on wider basic similarities. The danger, of course, is that we have oversimplified, and underplayed some of those crucial differences. The reader can be the judge.

Third, it is important that we categorically state that we are not putting forward a single cosmological model (with above and below worlds) applicable to all people, at all times, at all locations considered. While it is tempting to see preoccupations with the underworld as clearly reflecting ideas on the regeneration of the world - after all, rotting corpses and other biological materials clearly 'melt' into the ground as part of the decay process, and crops clearly grow out of the land - ethnographic studies show a diversity of attitude and meaning 
to the underworld, although many have ritual and/or religious significance (see, for example, Mbiti (1990) for African examples and Ahern (1973, Ch.13) on Chinese attitudes). The intention here is not to come up with a universal model, but to note similarities, invoke $a$ consistent narrative, and see where that takes us. If just one new avenue of enquiry results, that narrative will have served its purpose and we, or others, will move on to the next avenue that it in turn allows. Following Tilley (1994), we are less concerned with being 'right' about the meaning of things in the past, than in following means that allow us to see it 'differently'.

We begin by cataloguing some specific examples where the underworld has either been invoked as a theme, or where it seems to us an underworld 'perspective' might lead to further enquiry. We will end with summary remarks on the usefulness of the underworld as a theme.

\section{SPECIFIC EXAMPLES FOR DISCUSSION}

As stated above, the following categories are not exhaustive in defining every possible context for mediating with, approaching or entering the underworld. They have been largely self-selecting, in that previous authors have already mentioned the underworld (or similar) when discussing them. In each case primary references are initially quoted and used as examples.

\section{Caves/Fissures}

Chamberlain (1996) documented a noticeable clustering of cave burials in the UK dated to around and just after $5000 \mathrm{BP}$, and noted that the practice

"coincides with the practice of collective inhumation in chambered tombs and earthen long barrows" (Chamberlain 1996, p.951)

Barnatt and Edwards (2002) further discussed this use of caves during both the Neolithic and Bronze Age periods. They considered "caves as portals" (p.113), and that

"in effect, caves had a potential for use as places of seclusion where it was possible to come to commemorate, to commune with the spirits of the earth and to seek revelation. They were liminal environments" (p.125).

Furthermore, and echoing Chamberlain (1996) above, they suggested:

"natural cave passages could also be seen as the equivalents for, or antecedents to, Neolithic and earlier Bronze Age mortuary and funerary monuments which have chambers, cists and pits placed 'within the earth'” (p.114)

and summarised by stating that

"What is clear is that the use of caves in these ways echoes more basic traditions seen elsewhere. In the Neolithic, in particular, the act of deliberately placing chosen materials in the earth is a widespread phenomenon in western Europe" (p.126)

Here, the authors were referring back in the main to mortuary and funerary practices previously mentioned (and considered to some extent in some of the categories below).

Similarly, Tilley and Bennett (2001) considered that at West Penwith

"The caves and fissures in the rocks...may have been regarded as places where the ancestral beings who created the world entered and left it" (p.344) 
Again, the suggestion of caves and fissures as liminal environments is clear. In both papers an 'underworld' is implied, with caves and fissures as threshold locations where above- and below-ground worlds may connect.

\section{Sink-holes}

Sink-holes are openings into which surface water flows, disappearing underground. They may presently be filled with sediment, though excavations of such in-filled features have shown ritual deposition during the Neolithic and Bronze Age periods when they were presumably more open features (see, for example, Levitan et al. 1988; Stanton 1989).

There are good ethnographic data demonstrating that sink-holes are considered as entry points to an underworld and that the noise of water flowing underground near such features is also significant (e.g. Feld 1996). Archaeologists have also noted that such features may be locations where the inhabitants of the above-world can commune with inhabitants of the below-world, and have drawn on ethnography. Tilley (1994), for example, quotes Poole's (1986, p.175) discussion of sink-holes as significant locales for the Bimin-Kuskusnia in Papua New Guinea:

"At deep sinkholes the spirits of the dead find passage to the ancestral underworld, and ancestral spirits return through these passages to haunt and bless this domain".

In England a relationship has been noted between Neolithic monuments and sink-holes at Priddy Circle on Mendip (Stanton 1986; Bradley 2000). Also on Mendip, Lewis (2000), in assessing Neolithic and Bronze Age ritual deposition within several sink-holes (locally known as swallets), considered that

"Swallets are natural monuments in the Mendip landscape and appear to have had a very special meaning to prehistoric populations" (Lewis 2000)

For Iron Age Yorkshire, both Parker-Pearson (1999, p.132) and Woodward (2000, p.46) note associations between burials and sink-holes, the former explicitly stating that:

"The places in which water periodically appeared and disappeared may have been considered as entry points to the underworld". (Parker-Pearson 1999, p.132)

\section{Flint mines}

In his discussion of Neolithic flint 'mines' Russell (2002, p.24), makes a point of explaining that

“an attempt will be made to avoid the term flint 'mine', for it is clear that a significant number of shaft sites possess attributes unrelated to general mining activity".

This point has been amply demonstrated by two recent syntheses; one for England as a whole (Barber et al. 1999), the other for Sussex (Russell 2001). In many cases the shafts do not seem to have been primarily used for flint extraction, and some kind of ritual use and/or deposition seems more-or-less universal (see Barber et al. 1999, p.61-71 in particular), though some of this was of course closely-related to mining activity.

In discussing the backfilling of shafts Russell considers that such fills were designed to either shore up dangerous shafts or

"perhaps intended to heal partially the wound caused by the sinking of the shaft in the first place". (Russell 2002, p.107) 
Ritual deposition within such backfill is commonplace (Barber et al. 1999, p.72). Back-filling is also discussed in the section on ditches (below).

\section{Other natural and artificial shafts and wells}

Apart from caves, sink-holes and flint mines, there are a variety of other below ground features, both natural and artificial, that have been found to have associated evidence for ritual deposition. A particularly useful example is that of the recently excavated Fir Tree Field Shaft (Green and Allen 1997; Martin Green 2000) on Cranborne Chase, a now in-filled feature probably, though not proven to be, natural in origin. Analyses of the upper $7 \mathrm{~m}$ of fill revealed that the in-fill had accumulated from the Mesolithic to Beaker periods, and that some of the artefacts may have been ritually deposited. It was suggested

"that this, and other such natural features were regarded as sacred openings into 'mother earth', perhaps where rites of initiation, placation and communication could take place" (Martin Green 2000, p.14).

Green and Allen (1997) further discuss other natural (and artificial) shafts containing prehistoric archaeology.

Artificial shafts as ritual foci seem to have a long history. For the Neolithic one can mention ritual deposition within and adjacent to the Neolithic shaft at Monkton Up Wimborne, considered as perhaps dug to:

"placate the gods of the underworld who controlled nature itself" (Martin Green 2000, p.80).

For the earlier Bronze Age there is no better example than the Wilsford Shaft (Ashbee et al. 1989).

Later, there are many examples of Iron Age and Roman ritual use of wells and shafts (see, for example, Miranda Green 1986). Green states that in shafts at Hozhhausen, Germany and Swanwick, England the

"inference..... is that (of) human sacrifice(s) offered to a deity....perhaps of the underworld" (Green 1986, p.20).

It is pertinent, here, to remember that ritual use of natural features sunk into the earth goes back much further than the Neolithic, and that reverence for the 'power' of artificial and natural 'wells' does, of course, continue to the present day.

\section{Trees and tree-throw hollows}

Trees as objects in themselves (rather than wood as a material as posts) have rarely featured in archaeological discussion, although the uncovering of the inverted tree and associated circle at 'Seahenge', Holme-on-the-Sea, has promoted some recent comment, with Pryor (2001) considering that

"their life forces are being returned to the source of all life" (Pryor 2001, p.278)

before further going on to discuss the fact that inverted trees are viewed as 'growing' in the underworld by the Lapps, and thus linking above and below ground worlds (also, see Bradley 2000, p.12). It seems equally plausible, therefore, that one could view 'normally' oriented trees as growing simultaneously in the above ground world (our 'trunk', the underworld's 
'roots') and in the below world (our 'roots', their 'trunk'). The significance of straddling the above-below worlds is returned to below in the consideration of posts and stones.

Woodward (1992) further mentions large trees as probably venerated in the Iron Age and also documents whole trees being found in artificial or natural shafts, as does Green (1986, p.132133) who also makes specific links between trees and the underworld.

Evans et al. (1999) noted a significant presence of Neolithic artefacts in tree-throw hollows made by falling trees, and pointed out the similarity to structured deposition of artefacts in artificial pits. They considered that their presence possibly indicated caching of goods, and, more likely, occupation of the hollows using the throw-wall as a shelter. It is also, of course, plausible that the hollows were seen as openings into the underworld, and that the artefacts were ritual depositions akin to those found in the other openings discussed above and below.

\section{Ditches and mounds}

Ditch is here used to denote an excavation into the earth associated with one or more mounds (pits, which do not have associated mounds, are considered separately below). Mounds refer to either banks or other above ground artificial constructs with or without internal structures.

Many recent syntheses make it clear that structured deposition in ditches was commonplace throughout the Neolithic and into the Beaker Period (e.g. Malone 2001; Pollard and Reynolds 2002), either as a primary or secondary activity, and no further discussion of the actual nature and diversity of the 'offerings' is necessary here. In considering ditches at causewayed camps one author has stated that they can

"conceivably be seen as entry points to other worlds" (Malone 2001, p.76)

Also, in considering ditches associated with long mounds it has been stated that

"Ditch cuts may have performed a function that was originally considered as important as the mound itself' (Russell 2002, p.33)

When considering ditches, particularly perhaps those of causewayed enclosures, it may be worth entertaining the idea that in some cases the mounds or banks may actually be the largely inconsequential by-product of the digging of a ditch or ditches (see pits below also).

Mounds, including burial mounds, do not necessarily lend themselves to being explained as significant with respect to the underworld, although one author has seen long mounds as

"formal points of entry to the underworld where the gods were contacted and appeased".(Martin Green 2000, p.54)

and Barnatt and Edmonds (2002, p.114 quoted above) have pointed out that Neolithic and earlier Bronze Age burial and funerary monuments may have been modelled on the earlier use of natural caves. Clearly, Neolithic long mounds were not necessarily built for the dead themselves, since some did not contain human remains (Whittle 1996). It might be worthwhile pointing out, though, that if one considers 'inversion', as for trees (above), then chambered mounds could be viewed as being more than just modelled on caves, but as artificial constructions of caves and chambers in this world as viewed from the underworld. Here, they then are also liminal places where the living, dead and dwellers of the underworld (?ancestors) negotiate and mediate with one another. A similar argument may be put forward for henges with substantial banks and ditches. Whereas some have seen the vertical separation between top of bank and bottom of ditch as important in putting distance between the living and the underworld (see, for example, Pollard and Reynolds (2002, p.37) discussion on 
'verticality' at Avebury), it could be that the significance is actually in the structural symmetry created. Those above-ground can use the space created by a cut into the earth (the ditch); those in the underworld can make use of the space 'created' by the inverted 'ditch' of the bank (we should not necessarily be too bothered by the fact that to us this inverse 'ditch' (our bank) is solid - such solidity is of no consequence to those who inhabit the underworld what is important is the surface (either air-earth or earth-air) and the surface contour. Bradley's (2000, p.142-144) summarised discussion of the 'mirror' nature of footprint carvings in Scandinavia is helpful here, and this above-below symmetry will further considered in discussing posts and stones below. Inversion will be returned to again in the discussion.

\section{Pits}

It is widely recognised that

"As with the ditches of structured mounds and the fill of shafts, there would appear to be a significant quantity of placed deposits or structured debris recorded from the internal pits of Neolithic enclosure sites"...perhaps... "designed to claim the land, or as an offering to certain subterranean or supernatural forces" (Russell 2002, p.85)

Such pits may have been open for long periods of time and contain lots of ritual deposition, or have been back-filled immediately following excavation and containing no artefacts, although fragile textiles or organics being originally present cannot be ruled out (Pollard and Reynolds 2002). Where structured deposition does occur there do not seem to have been hard and fast rules governing such acts, though there is a widespread feeling that such pits are probably commemorative of unique events (e.g. Thomas 1999) and/or signifiers of belonging and ties to place (e.g. Edmonds 1999).

What are we to make of empty pits that were seemingly backfilled immediately after they were excavated? Perhaps in such circumstances we need to consider that the digging of a pit represents the creation of a locale in which mediation between those above and below ground takes place. If this is the case, then some mediations may have been rapid, with pits closed almost immediately, others more protracted or semi-permanent with complex, negotiations involving repeated or regular offerings.

\section{Postholes/posts and stoneholes/stones}

Upright posts and stones straddle the above-below ground boundary, and the fill of the holes into which posts and stones are placed often contain ritually deposited artefactual material, sometimes on an enormous scale such as at the West Kennet palisade enclosures (Whittle 1997). Equally often, though, such material is completely lacking, for example as at Sarn-YBryn timber circle (Gibson 1992). At the level of the individual site some post or stoneholes may contain goods, others not. As for pits (above), we perhaps need to see this variation (none-some-lots) as a reflection on the significance and/or duration of the mediation with the underworld at the site in general and/or at each particular opening and closing of a post or stonehole. In all cases where stones or timbers are left upright a 'gift' to the underworld is made in the shape of the stone or timber itself, and again we should be aware of the abovebelow ground symmetry of most of the stone or timber monuments themselves; not only do the individual stones or timbers straddle the above and below worlds, so to does the entire monument. As with wells, above, the offering of foundation deposits is still evident today.

\section{Springs, bogs, rivers and lakes}

The significance of springs, bogs, rivers and lakes as places in which propitious or reverential deposition of artefacts takes place is well established for British prehistory generally, though 
usually particularly discussed with respect to the Bronze and Iron Ages (e.g. Green 1986; Bradley 1990). This ample literature needs no introduction or indeed summary here. Springs can simply be viewed in the opposite manner to sink-holes (above), as locations where water from the underworld enters the above world. The folk-traditions surrounding some spring emergence sites have a long and increasingly well documented history (e.g. Jones 1992; Quinn 1999), and in recent years there has been some discussion of the relationship between springs and the landscape setting of prehistoric monuments or monument complexes (e.g. Richards 1996; Field 1999). Bogs have been particularly discussed with regard to the deposition of bodies, with Parker-Pearson explaining the phenomena as part of a general cosmology:

"The symbolic geography of the Iron Age was divided into three: the worthy dead above, fully transformed by fire into dry burnt bones and associated with things made through fire; the middle world of the living; and the wet underworld of the sacrificial and executed dead who were entirely untransformed and returned to an animal-like state" (Parker-Pearson 1999, p.70)

Bogs and other watery margins, rivers and lakes have, of course, also served as repositories for all manner of artefacts and products in the form of votive 'offerings'. Again, while this is best documented for the Bronze and Iron Ages (in particular because of well-studied contexts where metallic goods often survive well through time), there seem to be hints of a much longer tradition, with, for example, over half of all Neolithic axe finds from Ireland coming from rivers, bogs and lakes (Cooney et al. 1998). Coles et al. (1999) and Bradley (2000, p.61) discussed votive deposition going back at least to the Mesolithic period. One should not forget that the material being deposited is also of relevance, with organic materials deposited in rivers and lakes (and non-acidic bogs) much less likely to survive intact.

The meaning(s) behind votive deposition are debatable, and were probably quite varied, even personal to the individual undertaking the act or to the place in which the offerings were made (see, for example, Bradley 2000, Chapter 4). However, it has often been assumed that such locations

"presumably were gateways to a spirit world" (Parker-Pearson 1999, p.70)

and it is clear that springs, bogs, lakes and rivers can all be viewed as locations where the above and below ground worlds can readily be accessed. In the case of springs it may seem that considering them in opposition to sink-holes is most useful; for bogs, lakes and rivers it would seem that the significance lies rather more in the surface of the water suface as of liminal significance, a portal between above and below. Inversion, in the form of the reflected image, is once more a relevant phenomenon, particularly when the waters are still.

\section{Plough scatters}

Finally, we wish to consider scattered artefacts, especially those which can be regarded as plough scatters. Tilley (1994, p.205) made an astute observation with respect to the Neolithic in southern England (and beyond) in pointing out that earlier Mesolithic (surface) flint scatters would have had contemporary significance for a recognition reading and understanding of place, and that Neolithic monuments were located at places which were already recognised as significant. It may be that later, as farming became adopted, the deliberate spreading of artefactual material on the land was not just a response to declining fertility, or desire to improve the fabric of the soil, but also a social marker (as are static middens. See, for example, Evans 1999, p.57) - this is our place, we have a history here and we belong (see Evans 2003 for a recent discussion on this). Additionally, and perhaps more pertinent to the present paper, it should also be noted that such material was being spread where the earth had been scratched. 


\section{THE UNDERWORLD AS AN EXPLANATORY DEVICE}

In the light of the examples cited above, the following summary remarks can be made:

1. Many authors have invoked 'the underworld' in explaining aspects of prehistoric behaviour, though for pre-Iron Age times each has tended to do so only when explaining a particular act or set of acts. There has been little discussion, to date, of an overall cosmology involving an underworld prior to the Iron Age.

2. Nevertheless, this paper has demonstrated that wherever the earth was deliberately scratched by human agency, or naturally 'scratched' by what today would be recognised as a natural feature, ritual behaviour, in particular deposition, occurred. Furthermore, as demonstrated, in the case of most of the individual types of feature it has been accepted by one or more authors that an underworld is involved, and that such 'scratches' represent liminal locations - portals - where the aboveworlds and underworlds can interact. The case for looking at the underworld as a more general theme seems strong.

3. As well as considering mediation and negotiation between the above and below ground inhabitants, it is perhaps worthy of note that our conception of ancestral geographies still does not adequately address the up-down spatial dimension. While some authors have considered above ground verticality, we need to extend this below ground too and consider inversion as a widespread phenomena. If the actions of the underworld can be viewed from above, then the actions of the aboveground can be viewed from under. Particularly here we need to consider 'structures' that straddle the above-below. 'Structures' must be seen as a loose term since past populations may have viewed natural features as such. To illustrate this particular point further we can briefly consider another kind of 'pit' in the ground, naturally occurring dolines. Dolines are hollows in the ground surface formed by subsidence following dissolution of near surface bedrock. They may or may not have associated sink-holes (see above). Tilley (1999) noted that round barrows on the Ridgeway, South Dorset were located amongst dolines, with the suggestion that barrows are 'mirroring' the 'natural' structures. In other words barrows are inverted dolines and vice versa.

4. Following on from this, we can consider the following inversions as perhaps worthy of further consideration:

$\begin{array}{ll}\begin{array}{l}\text { Above ground feature } \\ \text { of significance }\end{array} & \text { related 'underworld' inversion } \\ \text { Cave } & \\ \text { Ditch } & \text { chambered or structured mound } \\ \text { Bank } & \text { bank } \\ \text { Doline } & \text { ditch } \\ \text { Tree } & \text { barrow } \\ \text { Post } & \text { tree } \\ \text { Stone } & \text { post } \\ & \text { stone }\end{array}$

The 'mirrored' inversion of islands in lakes may also contribute toward their importance as favoured loci too.

5. As Tilley (1994) makes clear in his general discussion on narrative, consideration here of the theme of the underworld (and consequently a phenomenon such as inversion) should be considered as $a$ narrative, not the narrative. As Tilley said 
"Walk from one place to another or approach it from another direction and everything will change" (Tilley 1994, p.74, our emphasis).

One of those directions is from below.

\section{ACKNOWLEDGEMENTS}

We are grateful to Bath Spa University College for supporting aspects of this work, and to colleagues there for discussions. We owe particular debts of gratitude to Christopher Tilley, for his volume A Phenomenology of Landscape, and to Richard Bradley, for An Archaeology of Natural Places. Both considered the theme of 'meaning' across broad temporal scales, and in particular demonstrated the role of 'modern' ethnographies in expanding our appreciation of the past.

\section{BIBLIOGRAPHY}

AHERN, E.A. 1973. The cult of the dead in a Chinese village. (Stanford, University Press).

ASHBEE, P., BELL, M. and PROUDFOOT, E. 1989: Wilsford Shaft: Excavations 1960-2 (London, HBMCE).

BARBER, M., NICHOLS, E., FIELD, D. and TOPPING, P. 1999: Neolithic flint mines in England (London, English Heritage).

BARNATT, J. and EDMONDS, M. 2002: Places apart: caves and monuments in Neolithic and earlier Bronze Age Britain. Cambridge Archaeological Journal 12 (1), 113-129.

BRADLEY, R. 1990: The passage of arms: an archaeological analysis of prehistoric hoards and votive deposits (Cambridge, Cambridge University Press).

BRADLEY, R. 2000: An archaeology of natural places (London, Routledge).

COLES, B., COLES, J. and SCHOU JØRGENSON 1999: Bog Bodies, Sacred Sites and Wetland Archaeology (Exeter, WARP Occasional Paper 12).

COONEY, G. AND MANDEL, S. 1998: The Irish Stone Axe Project, Monograph 1 (Dublin, Wordwell).

CUNLIFFE, B. 1983: Danebury: anatomy of an Iron Age Hillfort (London, Batsford).

EDMONDS, M. 1999: Ancestral Geographies of the Neolithic: landscapes, monuments and memory (London, Routledge).

EVANS, C., POLLARD, J. and KNIGHT, M. 1999: Life in woods: tree-throws, 'settlement' and forest cognition. Oxford Journal of Archaeology 18 (3), 241-254.

EVANS, J.G. 1999. Land and Archaeology (Stroud, Tempus).

EVANS, J.G. 2003. Environmental Archaeology and the Social Order. (London, Routledge).

FELD, S. 1996: Waterfalls of song. In Feld, S. and Basso, K.H. (eds.) Senses of Place. (Santa Fe: School of American Research Press), 91-135.

FIELD, D. 1999: Bury the dead in a secret landscape, British Archaeology, 43, 6-7. 
GIBSON, A. 1992: The timber circle at Sarn-y-Bryn-Caled, Welshpool, Powys; ritual and sacrifice in Bronze Age mid-Wales. Antiquity 66, 84-92.

GREEN, MARTIN 2000: A Landscape revealed: 10,000 years on a chalkland farm (Stroud, Tempus).

GREEN, MARTIN, and ALLEN, M.J. 1997: An early prehistoric shaft on Cranborne Chase. Oxford journal of Archaeology 16 (2), 121-132.

GREEN, MIRANDA. 1986: The gods of the Celts (Gloucester, Alan Sutton).

JONES, F. 1992: The holy wells of Wales (Cardiff, University of Wales Press).

LEVITAN, B., AUDSLEY, A., HAWKES, C., MOODY, A., MOODY, P., SMART, P. and THOMAS, J. 1988: Charterhouse Warren Farm Swallet, Mendip, Somerset. Proceedings of the University of Bristol Spelaeological Society 18(2), 171-239.

LEWIS, J. 2000: Upwards at 45 degrees: the use of vertical caves during the Neolithic and Early Bronze Age on Mendip, Somerset. Capra 2 available at http://www.shef.ac.uk/ capra/2/upwards.html

MALONE, C. 2001: Neolithic Britain and Ireland (Stroud, Tempus).

MBITI, J.S. 1990 (2 ${ }^{\text {nd }}$ edition). African Religions and Philosophies (Oxford, Heinemann)

PARKER-PEARSON, M. 1999: The Archaeology of Death and Burial (Stroud, Sutton Publishing).

POOLE, F. 1986: The erosion of a sacred landscape: European exploration and cultural ecology among the Bimin-Kuskusmin of Papua New Guinea. In Tobias, M (ed.) Mountain People (Oklahoma, University of Oklahoma Press).

PRYOR, F. 2001: Seahenge: New discoveries in prehistoric Britain. (London, Harper Collins).

QUINN, P. 1999: Monuments in the landscape, Volume VI: The Holy wells of Bath and Bristol region (Hertfordshire, Logaston Press).

POLLARD, J. and REYNOLDS, A. 2002: Avebury: biography of a landscape (Stroud, Tempus).

RICHARDS, C. .1996: Henges and water: towards an elemental understanding of monumentality and landscape in Late Neolithic Britain, Journal of Material Culture, 1 (3), 313-336.

RUSSELL, M. 2001: Rough Quarries, Rocks and Hills. (Oxford, Oxbow).

RUSSELL, M. 2002: Monuments of the British Neolithic (Stroud, Tempus).

STANTON, W. 1986: Natural Sinkholes Affecting the Priddy Circles, Mendip. Proceedings of the University of Bristol Spelaeological Society 17(3), 355-358.

STANTON, W. 1989: Beaker Age Deposits on Mendip at Charterhouse Warren Farm Swallet and Bos Swallet. Proceedings of the University of Bristol Spelaeological Society 18 (3), 395399. 
TILLEY, C. 1994: A Phenomenology of Landscape (Oxford, Berg).

TILLEY, C. 1999: Metaphor and Material Culture (Oxford, Blackwell).

TILLEY, C. and BENNETT, W. 2001: An archaeology of supernatural places: the case of West Penwith. Journal of the Royal Anthropological Institute 7, 335-362.

THOMAS .J. 1999: Understanding the Neolithic (London, Routledge).

TUAN, YI FU. 1974: Topophilia (New York, Prentice Hall).

WHITTLE, A. 1996: Europe in the Neolithic: The Creation of New Worlds (Cambridge, Cambridge University Press).

WHITTLE, A. 1997: Sacred Mound, Holy Rings: Silbury Hill and the West Kennet Palisade Enclosures - A Later Neolithic Complex in North Wiltshire (Oxford, Oxbow).

WOODWARD, A. 1992. Shrines and Sacrifice (London, Batsford).

WOODWARD, A. 2000. British barrows: a matter of life and death (Stroud, Tempus). 